\title{
Biosorption of Binary Mixtures of Copper and Cobalt by Penicillium brevicompactum
}

\author{
Kolishka Tsekova ${ }^{\mathrm{a}, *}$, Maria Ianis $^{\mathrm{a}}$, Vera Dencheva ${ }^{\mathrm{a}}$, and Sonya Ganeva ${ }^{\mathrm{b}}$ \\ a Department of Microbial Ecology, Institute of Microbiology, Bulgarian Academy of \\ Sciences, Sofia, Bulgaria. E-mail: kolishka@yahoo.com \\ b Faculty of Chemistry, Sofia University, Sofia, Bulgaria \\ * Author for correspondence and reprint requests \\ Z. Naturforsch. 62c, 261-264 (2007); received September 20/October 24, 2006
}

This work reports on a study of the biosorption of copper and cobalt, both singly and in combination (in equimolar concentrations), by the resting cells of Penicillium brevicompactum. Equilibrium batch sorption studies were carried out at $30^{\circ} \mathrm{C}$ and $\mathrm{pH} 5.0$ for a contact time of 1 hour to guarantee that equilibrium was reached. The equilibrium data were analyzed using the Langmuir and Freundlich isotherms. The adsorption of binary mixtures of heavy metal solutions on the fungal biomass was found to be of competitive type where the adsorption capacity for any single metal decreased in the presence of the other. The cobalt ions showed a higher affinity for Penicillium brevicompactum than the copper ions.

Key words: Heavy Metals, Competitive Sorption, Penicillium brevicompactum

\section{Introduction}

Increased industrialization and human activities have impacted on the environment through disposal waste containing heavy metals. Physicochemical methods for removing metals such as chemical precipitation, electrochemical treatment, ion exchange, and membrane technologies may be expensive and sometimes ineffective depending on heavy metal ion concentrations (Banerjee, 2002). Biological processes such as biosorption (bioaccumulation) using a microbial biomass have been proposed as alternative methods for removing and recovering heavy metals from industrial effluents with metal concentrations up to $100 \mathrm{mg} / \mathrm{L}$.

Although microbial-heavy metal interactions have long been investigated, the approach taken by most researchers has been to consider a single metal ion in a biological system (Kargi and Cikla, 2006; Vijayaraghavan et al., 2004; Gabriel et al., 2001). Such a situation rarely occurs in nature, and a study on the combined effect of two or more metals in the system would be more realistic and more important, but only a few works on the adsorption of a mixture of heavy metals were found in literature (Apiratikul et al., 2004; Kaewsarn, 2000; Chong and Volesky, 1995). Our previous work (Tsekova et al., 2005) illustrated the possibility of using Penicillium brevicompactum biomass for the biosorption of copper and cobalt ions in an aqueous solution for a single solute system. Moreover the interaction between both heavy metals could not be predicted based on single metal studies, and has not yet been investigated. The purpose of this work is therefore to investigate the competitive sorption of Penicillium brevicompactum in aqueous binary mixtures of copper(II) and cobalt(II) ions and to describe the two-metal biosorption equilibrium.

\section{Materials and Methods}

\section{Microorganisms, culture medium and growth} conditions

The fungus used in this study, Penicillium brevicompactum, is deposited at the Collection of the Institute of Microbiology at the Bulgarian Academy of Sciences. Spores of a 6- to 7-day-old culture incubated on potato-glucose agar slants at $30^{\circ} \mathrm{C}$ were used for inoculation (concentration of spore suspension $10^{6} / \mathrm{mL}$ ).

Cultivation of Penicillium brevicompactum was carried out in $500 \mathrm{ml}$ Erlenmeyer flasks with $100 \mathrm{ml}$ growth medium on a rotary shaker at $30{ }^{\circ} \mathrm{C}$. After $24 \mathrm{~h}$ cultivation the mycelium was centrifuged $(3000 \times g, 15 \mathrm{~min})$, washed with bidistilled water and used as a biosorbent. 


\section{Heavy metal uptake}

Classically, biosorption experiments were carried out in batches as follows: $1 \mathrm{~g}$ wet biosorbent was added to $100 \mathrm{ml}$ metal ions solution containing $0.5-4 \mathrm{~mm}$ of $\mathrm{CoCl}_{2} \cdot 6 \mathrm{H}_{2} \mathrm{O}$ or $\mathrm{CuSO}_{4} \cdot 5 \mathrm{H}_{2} \mathrm{O}$ in bidistilled water ( $\mathrm{pH} 5$ ) in Erlenmeyer flasks, which were then agitated at $220 \mathrm{rpm}$ on a rotary shaker for $1 \mathrm{~h}$ at $30^{\circ} \mathrm{C}$. In a second set of experiments, for the uptake of heavy metals, the biosorbent was suspended in $100 \mathrm{ml}$ of mixed solution (pH 5) containing equal concentrations of $\mathrm{CoCl}_{2}$. $6 \mathrm{H}_{2} \mathrm{O}$ and $\mathrm{CuSO}_{4} \cdot 5 \mathrm{H}_{2} \mathrm{O}$. The suspension was shaken for $1 \mathrm{~h}$ at $30^{\circ} \mathrm{C}$. Then the content of the flasks was separated by filtration using a Whatman No. 1 filter paper. The concentration of the metal ions in the filtrates was determined using an atomic absorption spectrophotometer with an air/ acetylene flame (model 2380; Perkin Elmer, Überlingen, Germany).

Uptake of metal ions was calculated from a metal mass balance yielding (Volesky, 1990): $q=V\left(C_{\mathrm{i}}-C_{\mathrm{f}}\right) / \mathrm{m} \mathrm{M}$, where $q$ is the heavy metal ions uptake (mmol/g dry biomass), $V$ is the sample volume $(\mathrm{L}), C_{\mathrm{i}}$ and $C_{\mathrm{f}}$ are the initial and residual metal concentrations $(\mathrm{mg} / \mathrm{L})$, respectively, $m$ is the amount of dry biomass (g) and $M$ is the molecular mass of the metal. Control samples with no added biomass were used as blanks.

\section{Results and Discussion}

The effect of metal concentration on $\mathrm{Cu}$ (II) and Co(II) biosorption by Penicillium brevicompactum in a single-metal as well as in binary-metal system is given in Fig. 1. A linear relationship was not observed for any of the cases investigated, but the heavy metal uptake capacities of fungal biomass were directly proportional to the initial metal concentrations. It can be observed from Fig. 1, that there was direct competition for the binding sites between $\mathrm{Cu}(\mathrm{II})$ and $\mathrm{Co}(\mathrm{II})$ ions in the binary metal system. Co(II) uptake overtook the uptake of $\mathrm{Cu}$ (II) at all tested concentrations.

Two different biosorption models were used to correlate the equilibrium data for heavy metals by Penicillium brevicompactum (Kargi and Cikla, 2006; Apiratikul et al., 2004). Biosorption equilibrium isotherms showing the relationship between equilibrium uptake $q_{\text {eq }}$ vs. residual metal concentration $C_{\mathrm{f}}$ were mathematically expressed by linearized Langmuir and Freundlich models. The values of $1 / q_{\text {eq }}$ were plotted against the values of $1 /$

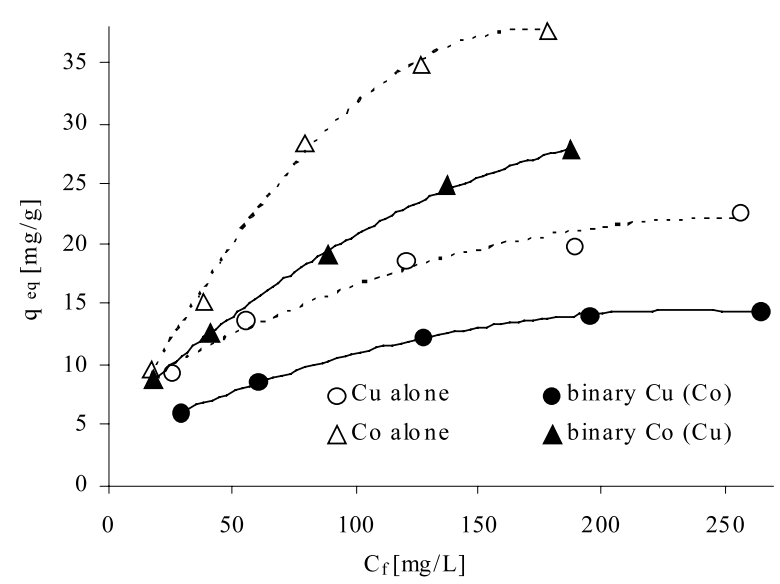

Fig. 1. Copper and cobalt biosorption by Penicillium brevicompactum. Initial $\mathrm{pH}$ value and biomass concentration in solutions were 5.0 and $1 \mathrm{~g} / \mathrm{L}$ as dry weight. $q_{\mathrm{eq}}$, equilibrium metal uptake; $C_{\mathrm{f}}$, residual metal concentration at equilibrium.

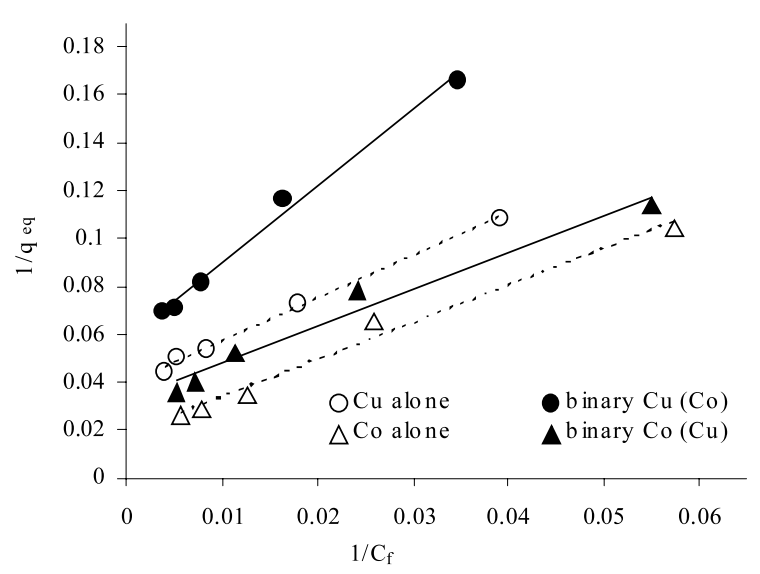

Fig. 2. Langmuir plots of heavy metals adsorption by resting cells of Penicillium brevicompactum derived from data shown in Fig. 1.

$C_{\mathrm{f}}$ yielding straight line relationships for each of $\mathrm{Cu}(\mathrm{II})$ and $\mathrm{Co}(\mathrm{II})$ as individual metal ions and also as binary mixtures (Fig. 2). Similarly the values of $\log q_{\text {eq }}$ were plotted against the values of $\log C_{\mathrm{f}}$, also giving straight lines for all tested conditions (Fig. 3). The values of $q_{\max }$ (maximum biosorption capacity, $\mathrm{mg} / \mathrm{g}$ ) and $K_{\mathrm{s}}$ (saturation constant, $\mathrm{mg} / \mathrm{L}$ ) as derived from the Langmuir isotherms and the Freundlich constants $K$ (capacity constant, $\mathrm{mg} / \mathrm{g}$ ) and $n$ (affinity constant) were obtained from the linear equations of both models.

Table I summarizes the results of the isotherm constants for the models tested. As it is obvious 
Table I. Langmuir and Freundlich model parameters for $\mathrm{Cu}(\mathrm{II})$ and $\mathrm{Co}(\mathrm{II})$ biosorption by resting cells of Penicillium brevicompactum.

\begin{tabular}{|c|c|c|c|c|c|c|}
\hline \multirow[t]{2}{*}{ Metal form } & \multicolumn{3}{|c|}{ Langmuir parameters } & \multicolumn{3}{|c|}{ Freundlich parameters } \\
\hline & $q_{\max }[\mathrm{mg} / \mathrm{g}]$ & $K_{\mathrm{s}}[\mathrm{mg} / \mathrm{L}]$ & $R^{2}$ & $K[\mathrm{mg} / \mathrm{g}]$ & $n$ & $R^{2}$ \\
\hline $\mathrm{Cu}$ alone & 25.32 & 45.34 & 0.996 & 2.83 & 2.64 & 0.977 \\
\hline Co alone & 54.64 & 84.41 & 0.985 & 1.64 & 1.60 & 0.980 \\
\hline Binary $\mathrm{Cu}(\mathrm{Co})$ & 17.39 & 55.97 & 0.992 & 1.56 & 2.43 & 0.978 \\
\hline Binary $\mathrm{Co}(\mathrm{Cu})$ & 30.96 & 48.21 & 0.970 & 1.98 & 1.97 & 0.997 \\
\hline
\end{tabular}

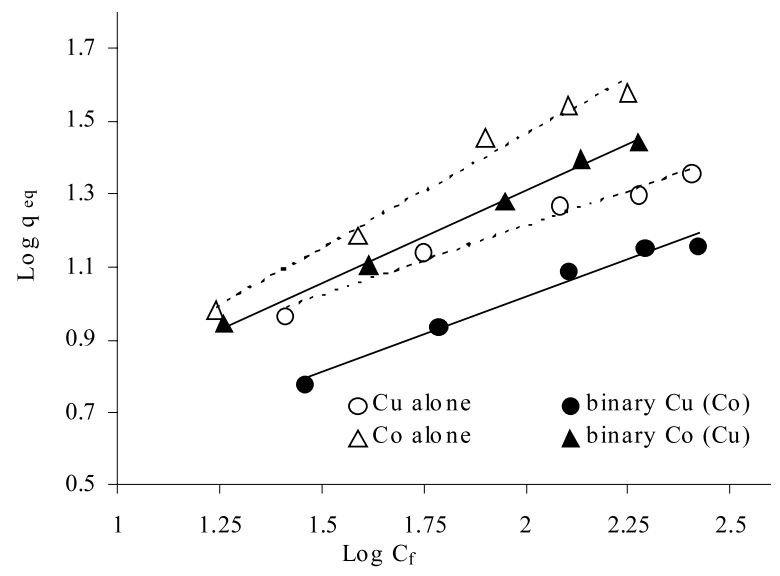

Fig. 3. Freundlich plots of heavy metals adsorption by resting cells of Penicillium brevicompactum derived from data shown in Fig. 1.

from Table I, the coefficients of determination $\left(R^{2}\right)$ of both models were close to one indicating that both models adequately describe the experimental data with slightly better performance on the Langmuir model, indicating that the adsorption leads to apparent deposition of a single layer of solute molecules on the adsorbent.

In general, the application of the Langmuir model indicated that the presence of one metal ion in the sorption system always lowers the sorption capacity for the other metal, an apparent case of sorption competition. The total adsorption capacity for the binary mixture was found to be always higher than the adsorption for $\mathrm{Cu}(\mathrm{II})$ alone but was almost the same as the adsorption of $\mathrm{Co}$ (II) in a single-component system. This indicated that the binding sites for both heavy metals might be the same and the adsorption of $\mathrm{Co}$ (II) was more favorable than the one for $\mathrm{Cu}(\mathrm{II})$ for this fungus. There are no reported data on $\mathrm{Cu}$ (II) and $\mathrm{Co}$ (II) biosorption from a binary-metal system to compare our results with. Therefore, as compared to the literature studies on biosorption of $\mathrm{Cu}(\mathrm{II})$ as well as $\mathrm{Co}(\mathrm{II})$ in a single-metal system, the biosorption capacity of Penicillium brevicompactum obtained in this study showed the range of the literature values for both heavy metals (Vijayaraghavan et al., 2004; Gabriel et al., 2001; Churchill et al., 1995). In his examination of the effect of other heavy metal ions on $\mathrm{Cu}$ (II) uptake by Durvillaea potatorum Kaewsarn (2000) reported that $\mathrm{Cu}$ (II) sorption was significantly affected by other heavy metals $\left(\mathrm{Ag}^{+}, \mathrm{Mn}^{2+}, \mathrm{Co}^{2+}, \mathrm{Ni}^{2+}, \mathrm{Zn}^{2+}, \mathrm{Fe}^{2+}\right.$, $\left.\mathrm{Cd}^{2+}, \mathrm{Pb}^{2+}\right)$ because the binding sites on the biosorbent were limited. So these ions competed simultaneously for the sites. The amount of suppression for $\mathrm{Cu}$ (II) uptake depended on the affinity of these ions for binding sites and binding strength of the respective heavy metal ions to the biosorbent. However, the adsorption of mixtures of $\mathrm{Cd}$ and $\mathrm{Cu}$, and $\mathrm{Pb}$ and $\mathrm{Cu}$ did not show a reduction in the total adsorption capacity as described by Apiratikul et al. (2004).

The results from this work indicated that there was a complex interaction between each metal species in the biosorbent. This finding is highly important for the design of adsorption systems for actual wastewater containing a mixture of $\mathrm{Cu}(\mathrm{II})$ and $\mathrm{Co}$ (II) as it provides the adsorption characteristic of the binary component mixture.

\section{Acknowledgements}

Grant B 1407/2004 allocated by the National Fond for Scientific Research to the Bulgarian Ministry of Education and Science supported this work. 
Apiratikul R., Marhada T., Wattanachira S., and Pavasant P. (2004), Biosorption of binary mixtures of heavy metals by green macro alga, Caulepra lentilifera, Songklanakarin. J. Sci. Technol. 26, 199-207.

Banerjee K. (2002), Economic evaluation of biosorption in comparison with other technologies for heavy metal removal. M.Sc. Dissertation, Environmental Engineering, Griffith University, Queensland.

Chong K. and Volesky B. (1995), Description of twometal biosorption equilibria by Langmuir-type models. Biotechnol. Bioeng. 47, 451-460.

Churchill S. A., Walters J. V., and Churchill P. F. (1995), Sorption of heavy metals by prepared bacterial cell surfaces. J. Environ. Eng. 121, 706-711.

Gabriel J., Baldrian P., Hladikova K., and Hakova M. (2001), Copper sorption by native and modified pellets of wood-rotting basidiomycetes. Lett. Appl. Microbiol. 32, 194-198.

Kaewsarn P. (2000), Single and multi-component biosorption of heavy metal ions by biosorption from ma- rine alga Durvillaea potatorum. Ph.D. Thesis, Environmental Engineering, Griffith University, Queensland.

Kargi F. and Cikla S. (2006), Biosorption of zinc(II) ions onto powdered waste sludge (PWS): Kinetics and isotherms. Enzyme Microb. Technol. 38, 705-710.

Tsekova K., Dencheva V., Ianis M., and Ganeva S. (2005), Sorption of copper and cobalt ions by species of genus Penicillium. Ecol. Eng. Environ. Prot. 1, $36-41$.

Vijayaraghavan K., Jegan J., Palanivelu K., and Velan M. (2004), Copper removal from aqueous solution by marine green alga Ulva reticulate. Electron. J. Biotechnol. 7, 62-67.

Volesky B. (1990), Removal and recovery of heavy metals by biosorption. In: Biosorption of Heavy Metals (Volesky B., ed.). CRC Press, Boca Raton, FL, pp. 7-14. 